\title{
Dietary protein, immune function and colon carcinogenesis in the mouse
}

\author{
Nádia Fátima G. PEREIRA DIAS, Valdemiro Carlos SGARBIERI*, \\ Helaine Beatriz JACOBUCCI, Humberto Araújo RANGEL, Cristina TANIKAWA \\ Department of Food and Nutrition, Faculty of Food Engineering, State University of Campinas, \\ Campinas, São Paulo, Brazil
}

\author{
Received 19 April 2005 - Accepted 10 February 2006
}

\begin{abstract}
Immune stimulation and colon cancer development were studied in A/J mice injected with azoxymethane (AOM) which were maintained on undenatured whey protein concentrate (WPC), Immunocal ${ }^{\mathrm{TM}}$ (IM), soy protein isolate (SPI) and a commercial casein (CC) as the only source of dietary protein for 32 weeks. No difference in growth rate and body weight was found for the different treatments. Immune stimulation, after challenge by subcutaneous injection of $5 \times 10^{6}$ sheep red blood cells, was evaluated by PFC (Plaque-Forming Cells) in the spleen. Response was equal and significantly higher for WPC- and IM-fed mice, the lowest response was found for the SPI group and an intermediate response for CC. A parallel increase was observed between PFC in the spleen and glutathione concentration in the liver. Aberrant crypt foci (ACF) were confirmed as reliable markers for colon carcinogenesis and were detected by fixation in formaldehyde solution and staining with methylene blue. A high linear correlation was found between ACF and actual number of colon tumors. The most important result of this work was the significant effect of the cysteine-rich proteins in the immunological response to SRBC antigen and tumor formation. These findings confirm and extend the works reported by other investigators.
\end{abstract}

mouse / colon cancer / azoxymethane / dietary protein / immunomodulation

摘要 - 膳食蛋白与小鼠免疫功和结肠癌的关系。本文系统研究了小鼠免疫刺激和结肠癌的 发展过程, 将氧化偶氮甲烷注射到 A/J 小鼠体内使其患结肠癌, 以未变性的乳清浓缩蛋白 (WPC)、乳清分离蛋白 (IM)、大豆分离蛋白 (SPI) 和商品干酪素 (CC) 作为试验小鼠的唯一膳 食蛋白饲喂 32 周。各处理组小鼠在体重和生长速率上没有显著性的差异。经皮下注射 $5 \times 10^{6}$ 的绵羊红细胞 (SRBC) 后, 根据测定小鼠脾脏溶血空斑形成数来评价小鼠的免疫刺激作用。 喂养乳清浓缩蛋白和乳清分离蛋白组小鼠的免疫应答相同且明显高于其他两组, 喂养大豆 分离蛋白试验组小鼠的免疫应答最低, 而喂养商品干酪素试验组小鼠的免疫应答则介于两 者中间; 同时小鼠脾脏溶血空斑形成数和肝脏中谷胱甘肽的浓度也相应地增加。异常阴窝 病灶 (ACF) 是结肠癌癌前病变的典型标志, 可采用甲醛溶液固定和亚甲基兰染色试验确定 阴窝异常病灶。试验证明异常阴窝病灶和实际结肠肿瘤的数量呈较高的线性关系。本项研 究得出最重要的结论是证明了富含半胱氨酸的蛋白质对 SRBC 抗原免疫应答和肿瘤的形成 具有显著的影响。这一结论证实和延伸了其他研究者的研究工作。

小鼠 I 结肠癌 I 氧化偶氮甲烷 $I$ 膳食蛋白 $/$ 免疫调节

Résumé - Protéines alimentaires, fonction immune et carcinogénèse du colon chez la souris. La stimulation immunologique et le développement du cancer de colon ont été étudiés chez des souris $\mathrm{A} / \mathrm{J}$ injectées avec de l'azoxyméthane (AOM) qui ont été soumises durant 32 semaines aux régimes

* Corresponding author (通讯作者): sgarb@fea.unicamp.br 
protéiques suivants : concentré de protéine non-dénaturée de sérum (WPC), Immunocal ${ }^{\mathrm{TM}}$ (IM), isolat de protéine de soja (SPI) et caséine commerciale (CC). Aucune différence n'a été observée pour la vitesse de croissance et le poids corporel, pour les différents traitements. La stimulation immunologique, après l'injection subcutanée de $5 \times 10^{6}$ hématies de mouton, a été évaluée par la formation cellulaire de plaque (PFC) dans la rate. La réponse a été significativement plus élevée pour toutes les souris alimentées avec WPC et IM, alors que la réponse la moins élevée a été trouvée dans le groupe SPI et une réponse intermédiaire pour le groupe CC. Une augmentation parallèle a été observée entre la formation cellulaire de plaque (PFC) dans la rate et la concentration en glutathion dans le foie. L'effet des protéines riches en cystéine dans la réponse immulogique à l'antigène des hématies de moutons (SRBC) et l'inhibition de la formation des tumeurs sont les résultats les plus importants de cette étude. Ces résultats confirment et étendent les résultats des travaux publiés par d'autres chercheurs.

souris / cancer du colon / azoxymethane / protéine alimentaire / immunomodulation

\section{INTRODUCTION}

Cancer is a multifactorial disease and diet seems to be one of the important factors [33]. Epidemiological studies suggest that diets rich in soybean products reduce the incidence of colon, mammary and prostate cancer $[1,6]$. For some investigators, the anticancer properties of soy products [5] may be attributed to the phytoestrogens such as genistein bound to the soy protein. Others [29], in a more critical examination of in vivo and in vitro studies, could not demonstrate a relationship between intake of soy foods, isoflavones (phytoestrogens) and colon cancer. Therefore, the association of soyfood intake with a decreased risk of certain types of cancer, particularly colon cancer, is still a subject of debate.

Evidence has been found [26, 27] that milk proteins are particularly efficient at retarding experimental colon tumorigenesis induced by dimethylhydrazine (DMH) in rats and mice. The antitumor effect of milk whey protein has also been demonstrated in vitro $[19,24]$ on various types of cancer cells. Although the mechanisms of the action of the whey proteins on colon cancer protection are still not understood, one of the hypotheses is that these proteins may act as immune modulators, probably through stimulation of tissue glutathione biosynthesis [12, 13]. Glutathione acts by protecting the tissues in various ways, therefore decreasing the toxicity of carcinogens and the risk of carcinogenesis [39].

In the present investigation the influence of different dietary proteins on the liver glutathione concentration, on the mouse immune system and on colon cancer induced by azoxymethane was comparatively studied.

\section{MATERIALS AND METHODS}

\subsection{Material of study}

The following sources of dietary protein were studied: (a) commercial casein purchased in the local market from M. Cassab Company, São Paulo, Brazil; (b) a commercial soy protein isolate (SPI), Samprosoy $90 \mathrm{NB}$, from the company Ceval Alimentos, São Paulo, Brazil; (c) Immunocal ${ }^{\mathrm{TM}}$ (IM), a whey protein isolate developed in Canada by Immunotech Research Ltd., VaudreiuilDarion, QC, and (d) a whey protein concentrate (WPC) produced in a pilot plant (Tecnolat), Institute of Food Technology, Campinas, São Paulo, Brazil.

Azoxymethane (AOM) from SigmaAldrich Company, St Louis, MO (USA) was used as a specific carcinogen to induce colon cancer in the mouse. All reagents used were analytical-grade and purchased from specialized suppliers. The ingredients for preparation of the experimental diets were analytical- or food-grade, acquired in the local market.

\subsection{Preparation of WPC}

The WPC used in this research was prepared as already reported [40]. Defatted and pasteurized $\left(72^{\circ} \mathrm{C}, 15 \mathrm{~s}\right)$ milk was obtained from a milk farmers' cooperative near the Food Technology Institute, Campinas. Upon 
arrival the milk was submitted to coagulation by commercial rennet (Christian Hansen, Valinhos, São Paulo, Brazil), for 45 to $60 \mathrm{~min}$ at $34{ }^{\circ} \mathrm{C}$. After mechanical breaking of the casein clot the whey was separated by filtration and concentrated $\left(38^{\circ} \mathrm{C}\right.$ ) by ultrafiltration (Koch Membrane Systems Inc. and WGM System, SP, Brazil - MW cut-off $10 \mathrm{~kg} \cdot \mathrm{mol}^{-1}$ ) to a concentration factor of 12. The operation was completed by diafiltration of the retentate with 15 cycles of deionized water. The retentate was then frozen and freeze-dried. All operations were performed at $38-40{ }^{\circ} \mathrm{C}$ to avoid protein denaturation.

\subsection{Chemical determinations}

The protein sources were characterized for centesimal composition and amino acid profiles. Moisture, ashes and protein $(\mathrm{N} \times \mathrm{F})$ were determined by the A.O.A.C. [3] procedures, using the appropriate factor for each protein. Total lipids were determined according to Bligh and Dyer [11] and carbohydrate was estimated by difference to $100 \%$ for the soy protein concentrate and as lactose for the other samples. Amino acids were determined from acid hydrolysate $\left(6 \mathrm{~N} \mathrm{HCl}, 110^{\circ} \mathrm{C}, 22 \mathrm{~h}\right)$, using a Dionex-D300 amino acid analyzer (Sunnyvale, CA, USA) by cation exchange chromatography and post-column ninhydrin reaction. For quantification a standard (Pierce) amino acid mixture was used. Tryptophan was determined in a pronase hydrolysate by the colorimetric method of Spies [34]. The essential amino acid adequacy was calculated based on the National Research Council's (NRC), USA, recommendation of essential amino acids for the growing mouse [22].

\subsection{Diet preparation}

The diets were prepared according to recommendations of the American Institute of Nutrition AIN-76A standard [2], modified for protein concentration $(20 \% \mathrm{w} / \mathrm{w})$ and total lipids $(15 \% \mathrm{w} / \mathrm{w})$. The lipid fraction was composed of pork lard (44.2\%), corn oil $(46.2 \%)$ and hydrogenated coconut fat $(9.6 \%)$, for the purpose of making the diets hyperlipidemic and hypercholesterolemic, which facilitates colon tumor development [33]. Other components present in the protein sources were taken into consideration for the diet formulation. The mineral and vitamin mixes were prepared from analytical-grade components, in accordance with A.I.N. (American Institute of Nutrition) [2] recommendations.

\subsection{Experimental animals and protocol}

The animals used were isogenic A/J female mice, of 6 to 7 weeks of age. Prior to being injected with the carcinogen (AOM) the mice were maintained for 4 weeks on the experimental diets, in isolators, 5 animals per cage. Subcutaneous injection of AOM started at the beginning of the 5th week and continued for 6 weeks (5 mg. $\mathrm{kg}^{-1}$ body weight) weekly, making a total dosage of $30 \mathrm{mg} \cdot \mathrm{kg}^{-1}$ body weight. A general experimental protocol is illustrated in Figure 1. The experimental protocol was approved by the Ethical Committee for Animal Experimentation, of the Institute of Biology, University of Campinas.

During the entire experiment the mice remained in isolators to prevent the possibility of external infection. All materials introduced into the isolators were sterilized. The diets were irradiated with a source of $\gamma$-rays (total dosage of $3 \mathrm{kGy}$ ), since preliminary experiments had shown that this irradiation dosage lowered microorganisms to safe levels without affecting the nutritional and immunological properties of the diets (data not shown).

According to Figure 1 the animals were sacrificed by cervical dislocation at the end of the 4th week $\left(T_{1}\right), 22$ nd week $\left(T_{2}\right)$ and 32 nd week $\left(\mathrm{T}_{3}\right)$. Five days prior to sacrifice the mice were injected subcutaneously with $5 \times 10^{6}$ sheep erythrocytes washed with borate buffer, with the purpose of stimulating immunologic reaction. Organs were collected and analyzed according to the fluxogram of Figure 2. 


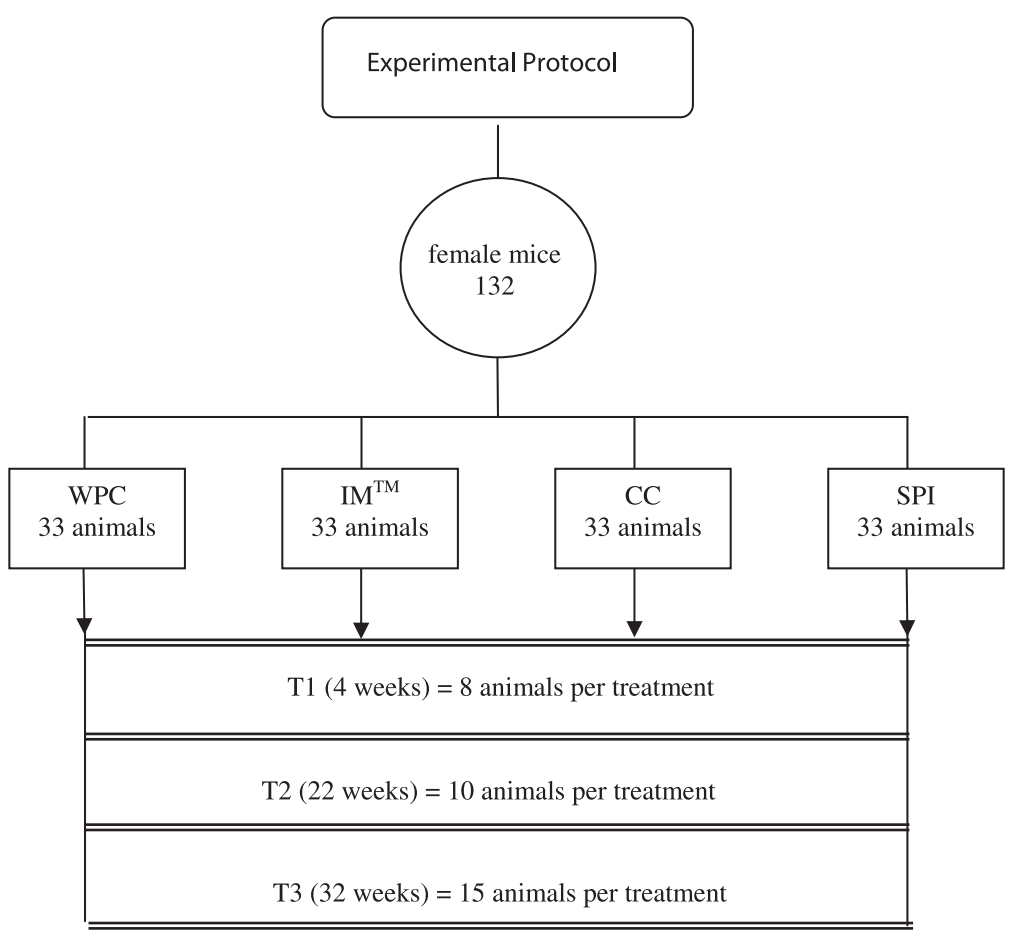

Figure 1. Schematic representation of the animal feeding trials designed to assess the impact of dietary protein source on colon tumorigenesis in the mouse. WPC, whey protein concentrate; IM ${ }^{\mathrm{TM}}$, Immunocal; CC, commercial casein; SPI, soy protein isolate. Diet, modified AIN-76A (20 g protein $100 \mathrm{~g}^{-1}$ diet).

\subsection{Procedures for monitoring the carcinogenesis}

The development of colon tumors was monitored by a close observation of the animals which in the period between the 16th and 24th weeks of experiment showed clinical signs of the presence of tumors such as blood in the feces, loss of hairs (alopecia), and opacity and discoloration of the eyes. The intestine, liver and spleen were collected at the time intervals specified in Figure 1 and analyzed for the purpose exemplified in Figure 2.

\subsubsection{Measurement of immunologic response}

The technique used for immune stimulation was the plaque-forming cells (PFC) according to the method modified by Cunningham and Szenberg [21] in cell suspensions of whole spleen five days after immunization, when the maximum count was observed. This technique was adapted to measure the reaction of IgM against specific sheep red blood cell (SRBC) antigen.

\subsubsection{Aberrant crypt foci (ACF)}

Aberrant crypts in the intestinal mucosa were determined by a histochemical fixation technique as described by Bird [7]. Aberrant crypt foci (ACF) were defined as spots containing 5 or more altered crypts.

\subsubsection{Liver glutathione determination}

Reduced glutathione (GSH) in the mice livers was determined by the method of 


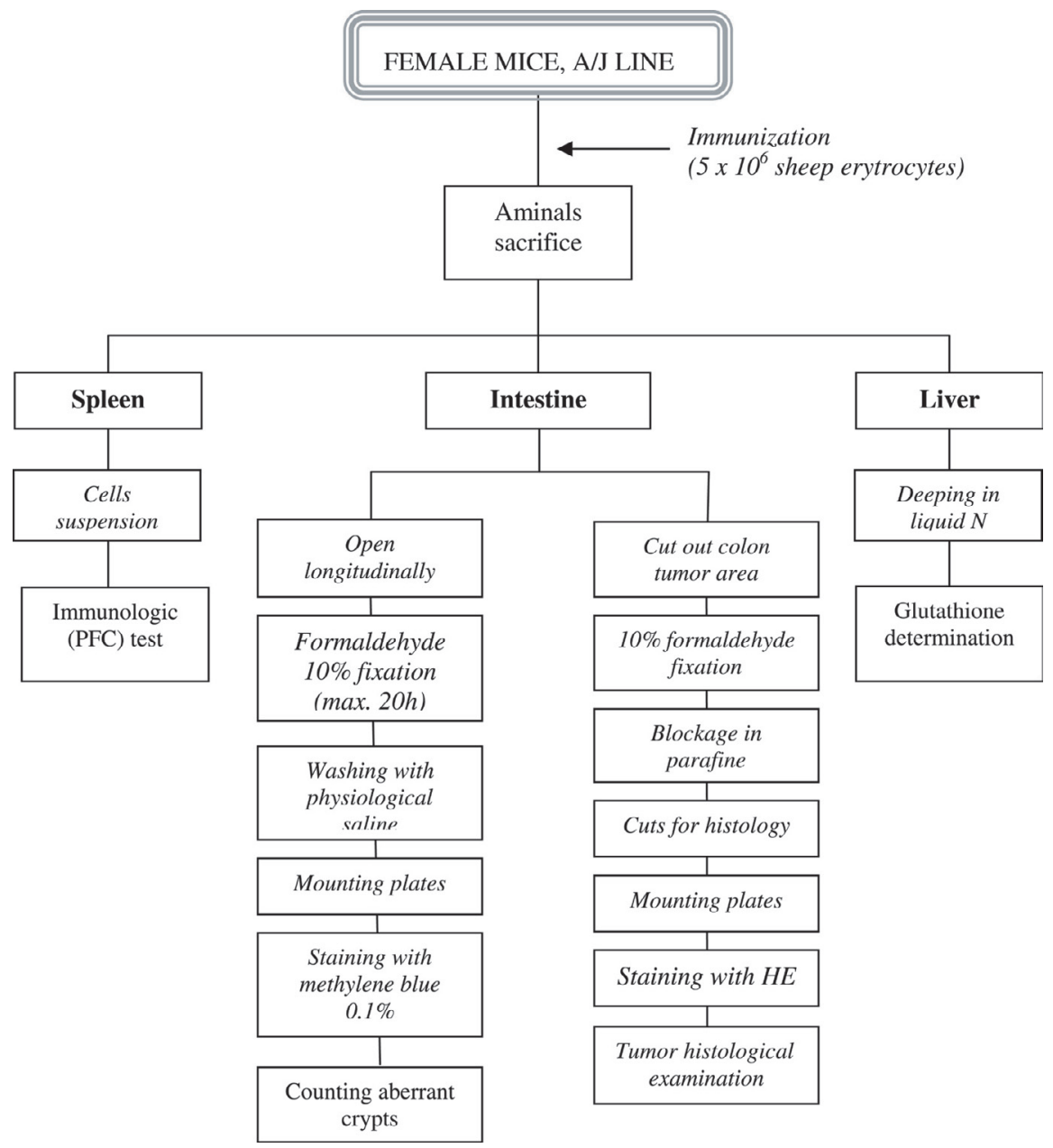

Figure 2. Schematic representation of analysis performed during colon cancer induction in mice.

Saville [30] and expressed as micromoles of GSH per gram fresh tissue.

\subsubsection{Number of tumors and anato- mophatologic examination}

The animals were sacrificed at various time intervals and the colons removed and opened longitudinally. After careful removal of the fecal content with saline $(0.9 \% \mathrm{NaCl}$ solution) the number of tumors was counted. Colon tumors were removed, fixed in formaldehyde and sent to a specialized labora- tory for histological and anatomophatologic examinations.

\subsection{Statistical analysis}

The experimental results were submitted to analysis of variance (ANOVA) and differences among means were evaluated by the Tukey test at a confidence level of $95 \%$ $(P<0.05)$ according to Gomes [23]. The Statistica: Basic Statistics and Tables Program was used. 
Table I. Proximate percent composition of the protein sources utilized in the formulation of the diets.

\begin{tabular}{lcccr}
\hline \multirow{2}{*}{ Component (\% dry basis) } & \multicolumn{4}{c}{ Protein sources $^{\mathrm{a}}$} \\
\cline { 2 - 5 } & WPC & IM & SPI & \multicolumn{1}{c}{ CC } \\
\hline Protein (N x F) & 83.4 & 91.5 & 92.0 & 84.3 \\
Total lipids & 4.5 & 0.12 & 0.5 & 1.4 \\
Ashes & 2.8 & 1.5 & 4.0 & 3.5 \\
Carbohydrate* & 8.9 & 6.9 & 3.5 & 10.8 \\
\hline
\end{tabular}

aWPC: whey protein concentrate; IM: Immunocal ${ }^{\mathrm{TM}}$; SPI: soy protein isolate; CC: commercial casein. SPI $(\mathrm{F}=6.25)$, WPC, IM and CC $(\mathrm{F}=6.38)$. Results are average of duplicate determinations. *Carbohydrate was determined as lactose, except for SPI (estimated by difference to $100 \%$ ).

\section{RESULTS}

\subsection{Percentual composition and amino acid profiles of the experimental protein sources}

The percentual chemical composition of the dietary protein sources studied in this investigation is shown in Table I. On a dry basis, protein ranged from $83.4 \%$ for WPC to $92 \%$ for SPI. Total lipids were highest $(4.5 \%)$ in the WPC and lowest $(0.12 \%)$ in the Immunocal ${ }^{\mathrm{TM}}$ (IM). Ashes were highest $(4.0 \%)$ in the SPI and lowest $(1.5 \%)$ in the IM. Carbohydrate, as lactose, was highest $(10.8 \%)$ in the commercial casein (CC) and lowest $(6.9 \%)$ in IM. SPI carbohydrate was estimated at $3.5 \%$ by difference with $100 \%$, summing up all other components.

The amino acid profiles of the dietary proteins used in this investigation are shown in Table II. The main differences noticed between the whey protein sources (WPC and IM), SPI and CC are the higher contents in the whey proteins of threonine, the S-containing amino acids (methionine and cysteine), the branched-chain amino acids (leucine and isoleucine), lysine and histidine. SPI presented a high content of arginine, which turns out to be essential, as well as histidine, for mouse growth.

In Table III the concentrations of the mouse essential amino acids in the experimental diets ( $20 \mathrm{~g}$ protein $\cdot 100 \mathrm{~g}^{-1}$ diet) are compared with the concentrations recommended by the USA National Research
Council (NRC) for the growing mouse. The whey proteins in both WPC and IM attained $100 \%$ of the requirements for mouse growth. A slight deficiency can be noticed for SPI and CC proteins in terms of the S-amino acids ( $92 \%$ and $88 \%$, respectively) of the recommended dietary concentrations.

\subsection{Body weight (in grams) of animals on the various treatments}

The body weight of the animals was recorded weekly during the entire experiment. Body weight of 10 mice (mean \pm sdm) at the beginning and at the end of the experiment did not show statistical differences $(P>0.05)$ in body weight gain among the groups fed different proteins (data not shown).

\subsection{Contents of glutathione in mice livers}

Table IV presents the concentration of glutathione in the mice livers before and after treatment with azoxymethane (AOM), a specific carcinogen for colon cancer. At the end of the 4th week, prior to AOM injection, and at the 32nd week, both IM and WPC showed significantly higher liver concentration of GSH than CC and SPI. No statistical difference $(P>0.05)$ was detected between WPC and IM, or between $\mathrm{CC}$ and SPI. At the end of the 32nd week the liver GSH concentration dropped for all the treatments but remained significantly higher $(P<0.05)$ for IM and WPC and 
Table II. Amino acid profiles of the dietary proteins used in the preparation of the experimental diets.

\begin{tabular}{|c|c|c|c|c|}
\hline $\begin{array}{l}\text { Amino acids } \\
\left(\mathrm{g} \cdot 100 \mathrm{~g}^{-1} \text { protein }\right)^{*}\end{array}$ & $\begin{array}{c}\text { Whey protein } \\
\text { concentrate (WPC) }\end{array}$ & $\begin{array}{l}\text { Immunocal }^{\mathrm{TM}} \\
\text { (IM) }\end{array}$ & $\begin{array}{c}\text { Soy protein isolate } \\
(\mathrm{SPI})\end{array}$ & $\begin{array}{c}\text { Commercial casein } \\
(\mathrm{CC})\end{array}$ \\
\hline Aspartic acid & 9.55 & 12.70 & 10.70 & 7.17 \\
\hline Serine & 5.14 & 5.30 & 5.00 & 5.93 \\
\hline Glutamic acid & 16.56 & 19.73 & 18.00 & 21.87 \\
\hline Proline & 5.55 & 6.30 & 4.70 & 9.97 \\
\hline Glycine & 1.66 & 2.00 & 3.70 & 1.80 \\
\hline Alanine & 4.42 & 5.60 & 3.70 & 3.03 \\
\hline Threonine ${ }^{\mathrm{a}}$ & 6.40 & 8.30 & 4.00 & 4.15 \\
\hline Valine $^{\mathrm{a}}$ & 5.04 & 6.80 & 3.80 & 6.16 \\
\hline Methionine & 2.02 & 2.23 & 1.29 & 1.21 \\
\hline Cystine & 3.48 & 3.01 & 1.01 & 0.99 \\
\hline Isoleucine ${ }^{\mathrm{a}}$ & 5.30 & 6.33 & 8.40 & 4.60 \\
\hline Leucine $^{\mathrm{a}}$ & 9.80 & 9.50 & 5.70 & 8.87 \\
\hline Phenylalanine & 3.21 & 3.18 & 5.04 & 5.32 \\
\hline Tyrosine $^{\mathrm{a}}$ & 2.87 & 3.15 & 3.36 & 5.76 \\
\hline Lysine $^{a}$ & 9.30 & 9.50 & 5.70 & 7.67 \\
\hline Histidine $^{\mathrm{a}}$ & 5.15 & 5.98 & 2.40 & 2.84 \\
\hline Arginine ${ }^{a}$ & 1.45 & 1.70 & 7.10 & 1.96 \\
\hline Tryptophan ${ }^{\mathrm{a}}$ & 1.12 & 2.00 & 0.90 & 1.40 \\
\hline
\end{tabular}

* Results are average of duplicate determinations.

a Essential amino acids for the mouse.

Table III. Essential amino acid concentration in the various diets ( $20 \mathrm{~g}$ protein $\cdot 100 \mathrm{~g}^{-1}$ diet $)$.

\begin{tabular}{lccccc}
\hline $\begin{array}{l}\text { Essential amino acid } \\
\text { \% in the diet) }\end{array}$ & $\mathrm{WPC}^{1}$ & $\mathrm{IM}^{2}$ & $\mathrm{SPI}^{3}$ & $\mathrm{CC}^{4}$ & $\begin{array}{c}\left.\mathrm{NRC}^{[22}\right] \\
\text { USA }\end{array}$ \\
\hline $\begin{array}{l}\text { Threonine } \\
\text { Valine }\end{array}$ & 1.28 & 2.77 & 0.64 & 0.84 & 0.40 \\
Methionine + & 1.00 & 1.28 & 0.80 & 1.24 & 0.50 \\
$\begin{array}{l}\text { Cystine } \\
\text { Isoleucine }\end{array}$ & 1.10 & 1.05 & $0.46^{*}$ & $0.44^{*}$ & 0.50 \\
Leucine & 1.06 & 1.36 & 0.76 & 0.92 & 0.40 \\
Phenylalanine + & 1.96 & 2.18 & 1.38 & 1.76 & 0.70 \\
Tyrosine & 1.22 & 1.27 & 1.68 & 2.22 & 0.40 \\
Lysine & & & & & \\
Histidine & 1.86 & 1.90 & 1.14 & 1.54 & 0.40 \\
Arginine & 1.04 & 1.20 & 0.48 & 0.56 & 0.20 \\
Tryptophan & 0.30 & 0.34 & 1.40 & 0.40 & 0.30 \\
Adequacy $(\%)$ & 0.22 & 0.40 & 0.18 & 0.28 & 0.10 \\
\hline
\end{tabular}

${ }^{1}$ Whey protein concentrate; ${ }^{2}$ Immunocal ${ }^{\mathrm{TM}} ;{ }^{3}$ Soy protein isolate; ${ }^{4}$ Commercial casein; ${ }^{[22]}$ USA National Research Council (NRC) recommendation for essential amino acid concentrations in the mouse diet. * The most limiting amino acids. 


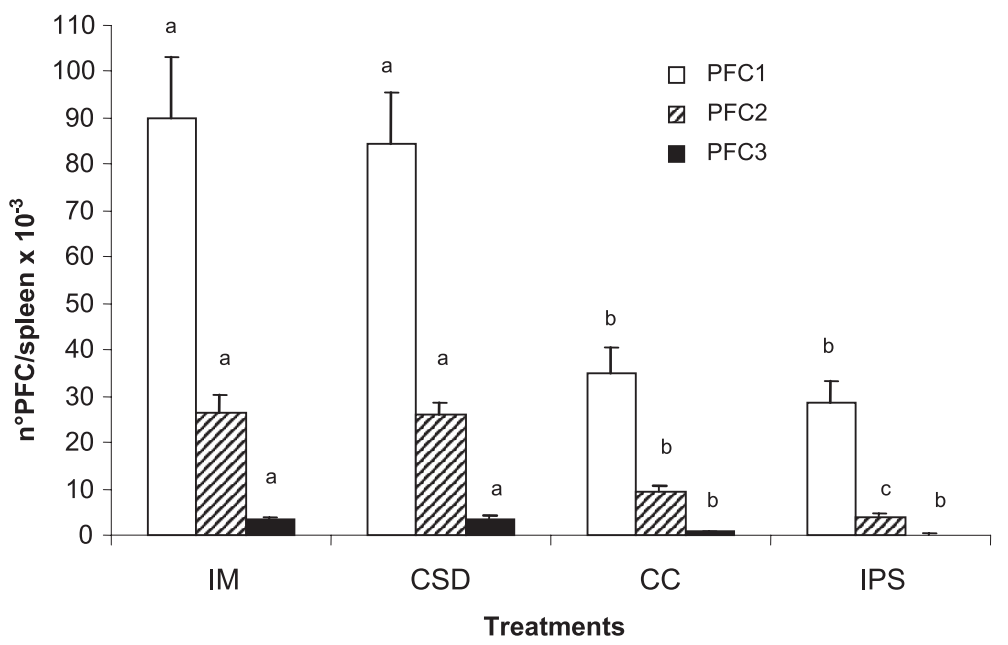

Figure 3. PFC (plaque-forming cells) as response of stimulation by sheep erythrocyte antigen, expressed per spleen of A/J female mice injected with AOM, after 4 weeks (PFC1), 22 weeks (PFC2) and 32 weeks (PFC3) of feeding the dietary proteins: IM, Immunocal TM; WPC, whey protein concentrate; SPI, soy protein isolate; $\mathrm{CC}$, commercial casein. ${ }^{\mathrm{a}, \mathrm{b}, \mathrm{c}}$ Different superscript letters indicate statistically different results $(P<0.05)$.

Table IV. Liver glutathione concentration of $\mathrm{A} / \mathrm{J}$ mice prior to treatment with azoxymethane (end 4th week) and after colon tumor development (32nd week).

\begin{tabular}{lcc}
\hline Treatments & \multicolumn{2}{c}{${\text { Glutathione }\left(\mu \mathrm{mol} \cdot \mathrm{g}^{-1}\right.}^{\text {fresh tissue })^{\mathrm{a}}}$} \\
\cline { 2 - 3 } & 4 weeks & 32 weeks \\
\hline Immunocal $^{\mathrm{TM}}(\mathrm{IM})$ & $9.14 \pm 1.26^{\mathrm{a}}$ & $5.19 \pm 0.91^{\mathrm{a}}$ \\
Whey protein concentrate (WPC) & $8.79 \pm 1.38^{\mathrm{a}}$ & $5.39 \pm 0.37^{\mathrm{a}}$ \\
Commercial casein (CC) & $5.32 \pm 0.43^{\mathrm{b}}$ & $2.74 \pm 0.46^{\mathrm{b}}$ \\
Soy protein isolate (SPI) & $4.53 \pm 0.81^{\mathrm{b}}$ & $1.88 \pm 0.44^{\mathrm{c}}$ \\
\hline
\end{tabular}

aAverage \pm standard deviation of 5 mice per treatment.

a,b,c Different small superscript letters (columns) indicate statistically different results $(P<0.05)$.

lower for $\mathrm{CC}$, which was superior $(P<0.05)$ to the SPI treatment. Therefore, the treatment with the carcinogen did not eliminate the superiority of IM and WPC compared with CC and SPI regarding maintenance of higher liver glutathione concentration.

The data in Figure 3 compare the PFC number per spleen of mice fed IM, WPC, $\mathrm{CC}$ and SPI at the end of the 4th $\left(\mathrm{PFC}_{1}\right)$, the 22nd $\left(\mathrm{PFC}_{2}\right)$ and the $32 \mathrm{nd}\left(\mathrm{PFC}_{3}\right)$ weeks of experiment. It became evident that the abil- ity of all four dietary proteins to modulate the reaction of immunoglobulin $\mathrm{M}(\operatorname{IgM})$ with SRBC antigen in the spleen decreased as the carcinogenesis progressed $\left(\mathrm{PFC}_{1}\right.$ to $\mathrm{PFC}_{3}$ ). This strongly suggests that carcinogenesis caused immune suppression in the mouse spleen. Nevertheless, it should be noticed that both IM and WPC maintained their superiority at modulating spleen plaque cell formation (PFC) compared with $\mathrm{CC}$ and SPI. 


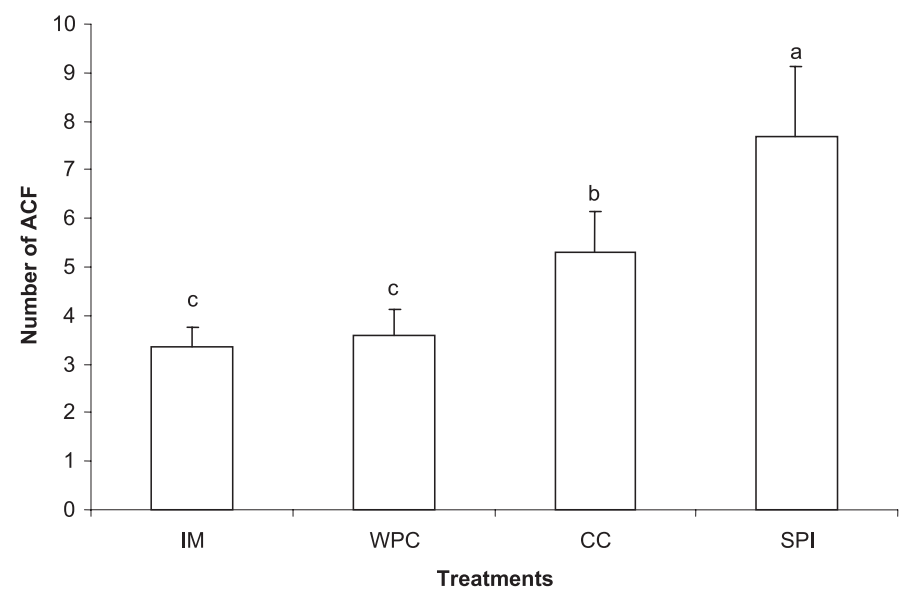

Figure 4. Occurence of aberrant intestinal crypt foci ( $\geq 5$ aberrant crypts/focus) in large intestine for mice treated with azoxymethane (16 weeks post-initiation). Dietary treatments: WPC, milk whey protein concentrate; $\mathrm{CC}$, commercial casein; SPI, soy protein isolate. ACF, aberrant crypt foci.

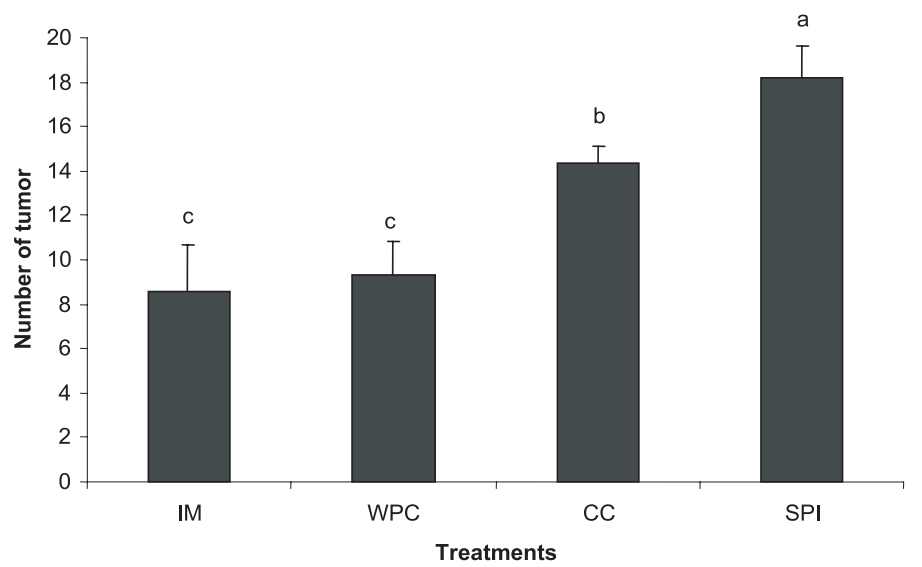

Figure 5. Incidence of tumors on A/J female mice's large intestine (20 animals/group) injected for 6 consecutive weeks with $5 \mathrm{mg} \cdot \mathrm{kg}^{-1}$ bw azoxymethane (AOM) and fed on a modified AIN-76A diet $\left(20 \mathrm{~g}\right.$ protein $\left.\cdot 100 \mathrm{~g}^{-1}\right)$ for 32 weeks (number of tumors - distal colon).

\subsection{Aberrant crypts and colon tumor development}

Epithelial cells' aberrant crypts have been described [7-10] as a good biological marker for colon cancer development.

In Figure 4 the number of aberrant crypt foci (ACF) found in the present work for the dietary sources studied is presented. Soy protein isolate (SPI) offered the least pro- tection against aberrant crypt foci formation $(P<0.05)$ followed by the commercial casein (CC), and by Immunocal ${ }^{\mathrm{TM}}$ (IM) and the whey protein concentrate (WPC). WPC and IM treatments presented the lowest ACF number with no statistical difference between them. Casein was intermediate between IM and WPC and superior to SPI.

Figure 5 shows the actual number of tumors formed for the dietary treatments 


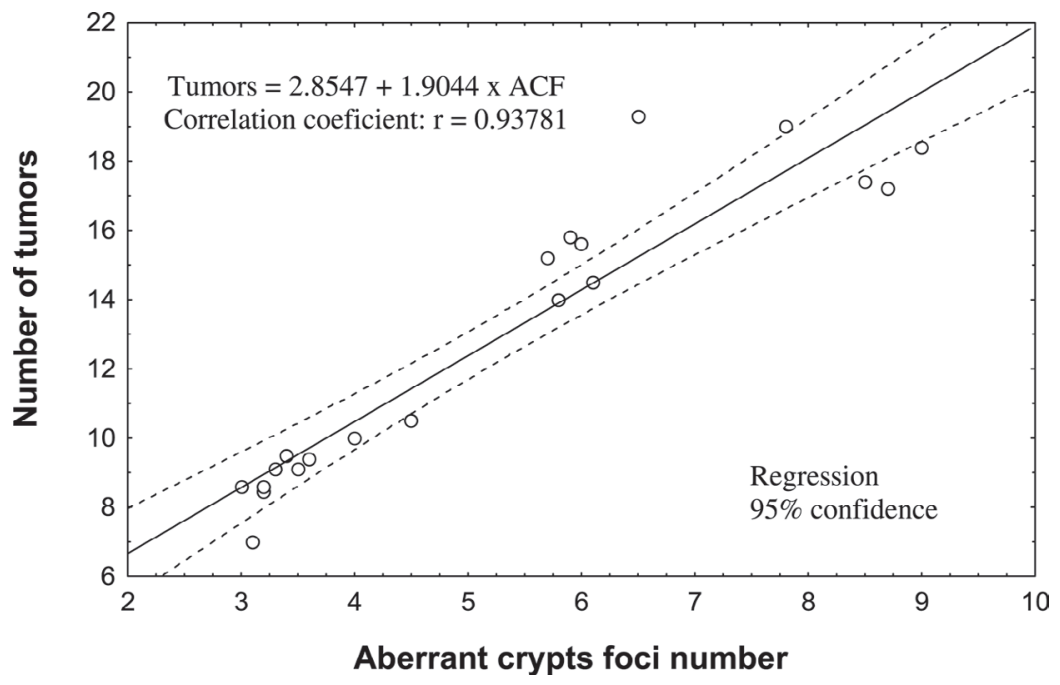

Figure 6. Linear correlation between aberrant crypt foci (ACF) and actual number of colon tumors developed in female mice by induction with azoxymethane.

and followed the same trend shown for ACF (Fig. 4). WPC and IM offered the highest protection against rat colon tumor formation followed by $\mathrm{CC}$ and SPI, which showed comparatively lower protection, all statistically different $(P<0.05)$. These results suggest once again that aberrant crypt foci (ACF) are good biological markers for colon tumor development in rodents (mouse and rats). A high linear coefficient correlation between the number of $\mathrm{ACF}$ and actual number of colon tumors in the mouse was demonstrated (Fig. 6).

After histological examination the tumors were classified as moderately differentiated adenocarcinoma, reaching the intestinal muscular layers. Adenomatous polyps were also a common finding in the histological preparations (not shown here).

\section{DISCUSSION}

The major finding in this investigation was the differential effects of the dietary proteins on the immunological response to sheep red blood cells and on the incidence of colon tumors. The whey protein (IM and WPC) diets showed significantly stronger immunemodulation to SRBC antigen than casein and soy bean, the SPI being the least stimulatory protein.

The incidence of colon tumors was significantly lower for the whey protein diets (IM and WPC) and highest for the SPI diet, showing that whey proteins protect against colon cancer better than casein and casein better than soy protein, in the rat.

These results are in accordance with and confirm previous findings of Bounous et al. $[15,16]$ and also of McIntosh et al. [27] showing the superiority of whey proteins compared with other food proteins tested, at protecting rodents against incidence and growth of colon cancer.

McIntosh et al. [27] compared the efficacy of whey protein, casein, meat protein and soybean (meal) on colon tumor incidence and retardation of tumor growth, in the rat. Whey protein was the most effective at controlling tumor incidence and growth while soybean meal $\left(20 \mathrm{~g}\right.$ protein $\cdot 100 \mathrm{~g}^{-1}$ diet) was the least efficient regarding incidence and growth of colon tumors. The rate 
of growth and body weight gain was superior for the rats on meat protein $(P<0.02)$ while no statistical differences were found for whey protein, soy protein or casein.

As shown in Table III the various diets used in this work practically covered the mouse's need for all essential amino acids [22], therefore eliminating any serious growthpromoting deficiency of the different diets.

Similar results have been reported $[15,16]$ for 6-week-old C3H male mice fed whey protein, soy protein and wheat protein at $\left(20 \mathrm{~g} \cdot 100 \mathrm{~g}^{-1}\right.$ diet $)$ for 3 weeks. No statistical difference $(P>0.05)$ was found in the rate of growth and body weight gain for the various dietary groups.

Immune modulation and intestinal tumor growth retardation have been reported as important properties of milk whey proteins [14-16, 27]. However, the mechanisms responsible for these properties are not fully understood.

Our data (Fig. 3) show that even under the immune-suppressive stress of the carcinogenesis the whey proteins (WPC and IM) were significantly superior to casein and soy protein at modulating the spleen cells to produce immunoglobulin M (IgM) when challenged by SRBC antigen. On the other hand, Table IV shows different liver glutathione concentrations for different dietary proteins, which parallel the measured difference in spleen PFC, establishing a relationship between tissue glutathione and immune stimulation. Bounous and collaborators $[13,17]$ hypothesized that the stimulus to glutathione synthesis in the mouse fed a whey protein diet should be explained by several glutamate-cystine sequences found in the primary amino acid sequences of various whey proteins ( $\beta$-lactoglobulin, $\alpha$-lactalbumin, bovine serum albumin and immunoglobulin). The glutamate-cystine are linked by disulfide bridges which cannot be hydrolyzed by the proteolytic digestive enzymes. Therefore, peptides with this sequence linked by disulfide bonds would be formed in the digestive tract from whey proteins and may be absorbed as such. The breaking of the disulfide bonds by specific enzymes, in the tissues, and releasing the dipeptide glutamyl-cysteine would stimulate glutathione synthesis by increasing the substrate for the glutathione synthetase. According to the above investigators glutathione is a key metabolite in the modulation of lymphocyte proliferation and cytokine production, which can lead to antibody (Ig) synthesis. It has been demonstrated [13] that by blocking the glutathione biosynthesis by subcutaneous administration of butathionine sulfoximine (BSO), a specific glutathione synthetase inhibitor, both the tissue glutathione increase and the spleen production of IgM are inhibited. This finding suggests a glutathione modulation in antibody production and an increase in tissue synthesis of glutathione by feeding the mouse undenatured whey proteins. In addition to the immune stimulatory function, whey protein and glutathione may also help to retard tumor development as natural antioxidants and free radical scavengers in tissue detoxication [39].

Evidence has been reported [25] that the dietary amino acid balance has an important effect on protein nutrition and therefore on tissue GSH homeostasis. In particular, the adequate provision of sulfur-containing amino acids as well as glutamate (related to glutamine or branched-chain amino acids) and glycine (or serine) is critical for the maximization of GSH synthesis. Increasing the supply of cysteine or its precursors (cystine, $\mathrm{N}$-acetyl cysteine, methionine and L2-oxothiazolidine-4-carboxylate) via oral or intravenous administration enhances GSH synthesis and prevents GSH depletion in humans and animals under various nutritional and pathological conditions, including protein malnutrition, adult respiratory distress syndrome, HIV and cancer [4, 25, 36]. Because methionine catabolism, via the transulfuration pathway (primarily in hepatocytes) can generate cysteine, dietary methionine can partly replace cysteine to support GSH synthesis in vivo.

Adequate GSH concentration is necessary for the proliferation of cells, including lymphocytes and intestinal epithelial cells [4]. In addition, GSH is essential for the activation of T-lymphocytes and polymorphonuclear leukocytes as well as for cytokine production and successful expression of immune responses, when the host cells are immunologically challenged [36]. 
Besides the many possible inhibitory actions of the GSH on tumor development such as immune stimulation, and detoxication of potentical carcinogens including xenobiotics and free radicals [18], some more complex mechanisms have been proposed $[20,31,32,37]$ for whey protein inhibition of AOM-induced intestinal ACF and colon tumor development. Bovine lactoferrin $[31,32]$ activates natural killer (NK) cells and a positive correlation between colon tumor incidence and carcinogeninduced depression of NK activity seems to exist.

Aberrant crypt foci (ACF), which were originally described by Bird [7] in the murine colon exposed to the colon-specific carcinogen azoxymethane (AOM), have been recognized as early preneoplasic lesions. In the present work (Fig. 6) a strong correlation was demonstrated between aberrant crypt foci number and the actual number of colon tumors, in the various dietary protein treatments.

Studies on carcinogen specificity [28] showed that, in addition to azoxymethane, several other colon-specific carcinogens such as 1,2-dimethylhydrazine, 4-aminobiphenyl, N-nitroso-N-methylurea and 3methylcholanthrene also induced ACF, indicating that the development of these lesions in the colon is clearly related to genotoxic events. Genetic studies [35, 38] of $\mathrm{ACF}$ revealed that mutations in the gene k-ras are frequently identified in these lesions. Because colonic tumors developed by chemical carcinogens are also reported to show frequent mutation in the k-ras gene, a similarity is apparent between the $\mathrm{ACF}$ and colonic tumor genotype, suggesting that these genetic alterations may play a key role in the development of colonic ACF and colon tumors as well.

\section{CONCLUSION}

At the protein concentration used in this work practically all essential amino acids recommended for mouse growth were provided by the diets. Therefore, it can be concluded that no nutritional deficiency was imposed upon the mice in the various diets.
The higher S-amino acid content, particularly of cysteine, in whey proteins modulates higher tissue glutathione biosynthesis and higher immune stimulation than the other proteins tested such as casein and soybean protein. Higher control of colon carcinogenesis by whey protein has been attributed to its differentiated amino acid composition which is related to higher glutathione biosynthesis and stronger immune stimulation.

The complete mechanism by which whey proteins retard colon cancer incidence and growth is not completely understood and has yet to be elucidated.

Acknowledgements: The authors wish to acknowledge the financial support given by FAPESP (Fundação de Amparo à Pesquisa do Estado de São Paulo) for this work. Acknowledgement is also due to $\mathrm{CNPq}$ (Conselho Nacional de Desenvolvimento Científico e Tecnológico) for the scholarship granted to the first author.

\section{REFERENCES}

[1] Adlercreutz C.H., Goldin B.R., Gorbach S.L., Hockerstedt K.A., Watanabe S., Hamalainen E.K., Markkanen M.H., Makela T.H., Wahala K.T., Adlercreutz T., Soybean phytoestrogen intake and cancer risk, J. Nutr. 125 (1995) $757 \mathrm{~S}-770 \mathrm{~S}$

[2] American Institute of Nutrition, AIN-76A Standards for Nutritional Studies Report. Report of the American Institute of Nutrition Ad Hoc Committee on Standards for Nutritional Studies, Bethesda, Bethesda, USA, 1977.

[3] Association of Official Analytical Chemists, Official Methods of Analysis, 15th edn., Washington DC, USA, 1990.

[4] Aw T.Y., Cellular redox: a modulator of intestinal epithelial cell proliferation, News Physiol. Sci. 18 (2003) 201-204.

[5] Barnes S., Peterson T.G., Coward L., Rationale for the use of genistein - containing soy matrices in chemoprevention trials for breast and prostate cancer, J. Cell. Biochem. 22 (Suppl.) (1995) 181S-185S.

[6] Bennink M.R., Om A.S., Inhibition of colon cancer (CC) by soy phytochemicals but not by soy protein, Fed. Amer. Soc. Exp. Biol. J. 12 (1998) A655. 
[7] Bird R.P., Observations and quantification of aberrant crypts in the murine colon treated with a colon carcinogen: preliminary findings, Cancer Lett. 37 (1987) 147-151.

[8] Bird R.P., Role of aberrant crypt foci in understanding the pathogenesis of colon cancer, Cancer Lett. 93 (1995) 55-71.

[9] Bird R.P., Aberrant crypt foci to study cancer preventive agents in the colon, in: Hanaucek M., Walaaszek Z. (Eds.), Tumor Marker Protocols, Human Press Inc., New Jersey, USA, 1998, pp. 465-474.

[10] Bird R.P., Good C.K., The significance of aberrant crypt foci in understanding the pathogenesis of colon cancer, Toxicol. Lett. 112/113 (2000) 395-402.

[11] Bligh E.G., Dyer W.J., A rapid method of total lipid extraction and purification, Can. J. Biochem. Physiol. 37 (1959) 911-917.

[12] Bounous G., Whey protein concentrate (WPC) and glutathione modulation in cancer treatment, Anticancer Res. 20 (2000) 47854792.

[13] Bounous G., Gold P., The biological activity of undenatured dietary whey proteins: role of glutathione, Clin. Invest. Med. 14 (1991) 296-309.

[14] Bounous G., Kongshavn P.A.L., Differential effect of dietary protein type on B-cell and Tcell immune response in mice, J. Nutr. 115 (1985) 1403-1408.

[15] Bounous G., Létourneau L., Kongshavn P.A.L., Influence of dietary protein type on the immune system of mice, J. Nutr. 113 (1983) 1415-1421.

[16] Bounous G., Papenburg R., Kongshavn P.A.L., Gold P., Fleiszer D., Dietary whey protein inhibits the development of dimethylhydrazine induced malignancy, Clin. Invest. Med. 11 (1988) 213-217.

[17] Bounous G., Batist G., Gold P., Immunoenhancing property of dietary whey protein in mice: role of glutathione, Clin. Invest. Med. 12 (1989) 154-161.

[18] Bounous G., Batist G., Gold P., Whey proteins in cancer prevention, Cancer Lett. 57 (1991) 91-94.

[19] Bourtourault M., Buleon R., Samperez S., Jouan P., Effet des protéines du lactosérum bovin sur la multiplication de cellules cancéreuses humaines, C.R. Soc. Biol. 185 (1991) 319-323.

[20] Britigan B.E., Serody J.S., Cohen M.S., The role of lactoferrin as an anti-inflammatory molecule, Adv. Exp. Med. Biol. 357 (1994) 143-156.
[21] Cunningham A., Szenberg A., Further improvements in the plaque technique for detecting single antibody forming cells, Immunology 14 (1968) 599-600.

[22] De Luca R.R., Alexandre S.R., Marques T., Souza N.L., Merusse J.L.B., Neves S.P. (Eds.), Manual para técnicas em bioterismo (English translation), $2^{a}$ Edição, Colégio Brasileiro de Experimentação Animal, São Paulo, Brazil, 1996.

[23] Gomes F.P., Curso de Estatística Experimental, $10^{a}$ Edição, Nobel, Piracicaba, São Paulo, Brazil, 1982.

[24] Hakanson A., Zhivotovsky B., Orrenius S., Sabharwal H., Svanborg C., Apoptosis induced by a human milk protein, Proc. Natl. Acad. Sci. USA 92 (1995) 8064-8068.

[25] Lu S.C., Regulation of glutathione synthesis, Curr. Top. Cell. Regul. 36 (2000) 95-116.

[26] McIntosh G.H., Le Leu R.K., The influence of dietary proteins on colon cancer risk, Nutr. Res. 21 (2001) 1053-1066.

[27] McIntosh G.H., Regester G.Q., Le Leu R.K., Royle P.J., Smithers G.W., Dairy proteins protect againt dimethylhydrazine-induced intestinal cancers in rats, J. Nutr. 125 (1995) 809-816.

[28] McLellan E.A., Bird R.R., Specificity study to evaluate induction of aberrant crypts in murine colons, Cancer Res. 48 (1988) 61836186.

[29] Messina M., Bennink M., Soyfoods, isoflavones and risk of colon cancer: a review of the in vitro and in vivo data, Clin. Endocrinol. Metab. 12 (1998) 707-728.

[30] Saville B., A scheme for the colorimetric determination of microgram amounts of thiols, Food Chem. 83 (1958) 670-673.

[31] Sekine K., Ushida Y., Kuhara T., Ligo M., Baba-Toriyama H., Moore M.A., Murakoshi M., Satomi Y., Nishino H., Kakizoe T., Tsuda H., Inhibition of initiation and early stage development of aberrant crypt foci and enhanced natural killer activity in male rats administered bovine lactoferrin concomitantly with azoxymethane, Cancer Lett. 121 (1997) 211-216.

[32] Sekine K., Ushida Y., Kuhara T., Watanabe E., Nakamura J., Takasuka N., Kim D.J., Asamoto M., Krutovskikh V., Baba-Toriyama H., Ota T., Moore M.A., Masuda M., Sujimoto H., Nishino H., Kakizoe T., Tsuda H., Inhibition of azoxymathane-initiated colon tumor by bovine lactoferrin administration in F344 rats, Jap. J. Cancer Res. 88 (1997) 523526. 
[33] Sgarbieri V.C., The role of dietary energy and macrocomponents of foods in modulating carcinogenesis (an overview), Ciência e Cultura 51 (1999) 104-121.

[34] Spies J.R., Determination of tryptophan in proteins, Anal. Chem. 39 (1967) 1412-1415.

[35] Stopera S.A., Murphy L.C., Bird R.P., Evidence for a ras gene mutation in azoxymethane-induced colonic aberrant crypts in Sprage-Dawley rats: earliest recognizable precursor lesions of experimental colon cancer, Carcinogenesis 13 (1992) 2081-2085.

[36] Towsend D.M., Tew K.D., Tapiero H., The importance of glutathione in human disease, Biomed. Pharmacother. 57 (2003) 145-155.

[37] Ushida Y., Sekine K., Kuhara T., Takasuka N., Ligo M., Tsuda H., Inhibitory effect of bovine lactoferrin on intestinal polyposis in the ApcMin Mouse, Cancer Lett. 134 (1998) 141-145.

[38] Vivona A., Shpitz B., Medline A., Bruce W., Hay K., Ward M., Stern H., Gallinger S., K-ras mutations in aberrant crypt foci, adenomas and adenocarcinomas during azoxymethane-induced colon carcinogenesis, Carcinogenesis 14 (1993) 1777-1781.

[39] Wu G., Fang Y.-Z., Young S., Lupton J.R., Turner N.D., Glutathione metabolism and its implications for health, J. Nutr. 134 (2004) 489-492.

[40] Zinsly P.F., Sgarbieri V.C., Dias N.F.G.P., Jacobucci H.B., Pacheco M.T.B., Baldini V.L.S., Produção piloto de concentrados de proteína de leite bovino: Composição e valor nutritivo, Braz. J. Food Technol. 4 (2001) 1-8. 